\title{
PENGARUH MOTIVASI, KEMAMPUAN, PERSEPSI PERAN TERHADAP KEPUASAN PEGAWAI DI DINAS KEBUDAYAAN DAN PARIWISATA PROVINSI BENGKULU
}

\author{
Febzi Fiona \\ Jurusan Manajemen, Fakultas Ekonomi dan Bisnis, Universitas Bengkulu
}

\begin{abstract}
The purpose of this research is to investigated the influence of ability and role perception to employee job satisfaction) at Dinas Kebudayaan dan Pariwisata Provinsi Bengkulu. This research use quantitative methods and qualitative methods. Data that used in this research is primary data of questionnaire. Population of the current research is 157 people. Distributing questionnaires to employees at Dinas Kebudayaan dan Pariwisata Provinsi Bengkulu taken as many as 113 people with proportionate stratified random sampling methodsAnalysis technique that used in this research is Regression Analysis from software SPSS 17. The result indicates that ability have a positive and significant effect to job satisfaction, role perception have a positive and significant effect to job satisfaction.
\end{abstract}

Keywords : Ability, Role Perception, Job Satisfaction

\section{PENDAHULUAN}

Pariwisata di Indonesia merupakan sektor ekonomi penting di Indonesia. Pada tahun 2009, pariwisata menempati urutan ketiga dalam hal penerimaan devisa setelah komoditi minyak dan gas bumi serta minyak kelapa sawit. Dari data yang didapatkan dari kementerian kebudayaan dan pariwisata ini perlu di apresiasi tinggi dan dikelola dengan baik peningkatan pariwisata di Indonesia. Pernyataan dari Menteri Pariwisata Arief Yahya mengemukakan bahwa kesuksesan pengembangan pariwisata di daerah ditentukan oleh kepala daerah yaitu gubernur, bupati dan wali kota. Selanjutnya jika kepala daerah tahu bagaimana mengalokasikan sumber daya, pariwisata akan maju. Kalau tidak tahu gawat dan berbahaya, (Antara News, 12 mei 2016)

Motivasi kerja mempunyai peranan yang sangat penting dalam suatu organisasi dan juga mempunyai akibat yang positif terhadap keberhasilan 
usaha bersama. Motivasi kerja yang tinggi akan berpengaruh terhadap pegawai dalam bekerja sehingga mendorong pegawai untuk bekerja dengan sebaik-baiknya (Robbins, 2008).Peningkatan persepsi peran bagi pegawai akan memberikan hasil kerja yang optimal karena mereka merasa bertanggung jawab akan tugas yang diberikan oleh organisasi ini. Menurut Keith Davis (2002:85) mengatakan aktivitas para manajer dan pegawai diarahkan oleh persepsi peran (role perceptions) mereka, yaitu apa yang harus dilakukan menurut pandangan mereka dalam peran mereka sendiri, dan bagaimana seyogianya orang lain bertindak dalam peran mereka. Sehingga setiap pegawai di berikan kebebasan dari segi pandang mana dalam melakukan peran untuk mengerjakan tugas dan bertindak dalam peran mereka untuk mendapatkan hasil kerja yang optimal, Penerapan dari motivasi, kemampuan dan persespsi peran akan mempengaruhi kepuasan kerja. Kepuasan kerja pegawai dapat dihubungkan dengan kinerja dan hasil kinerja mereka serta imbalan dan hukuman yang akan diterima.

Setelah membaca kebijakan dari pemerintah dan anjuran dari Menteri Pariwisata disini penulis mengambil objek penelitian di Bengkulu, Bengkulu adalah salah satu provinsi di Indonesia yang dibentuk berdasarkan UndangUndang No.9 Tahun 1967. Peraturan Pemerintah No.20 Tahun 1968, terletak di bagian Barat Pulau Sumatera, yang terkenal dengan sebutan Bencoolen dan merupakan tempat tumbuhnya bunga Rafflesia Arnoldi yang merupakan bunga terbesar di dunia. Bengkulu terletak di pesisir barat Pulau Sumatra dan berhadapan langsung dengan Samudera Indonesia. Bengkulu juga salah satu tempat pembuangan sejumlah aktivis pejuang kemerdekaan, termasuk Bung Karno yang diasingkan ke dari tahun 1938-1941. Di masa inilah Bung Karno berkenalan dengan Fatmawati yang kemudian menjadi isterinya. Keunikan tempat wisata di Bengkulu yang dapat ditemukan dalam sejumlah pesona alam dan peninggalan sejarah yang mempesona. Beberapa daya tarik tempat pariwisata yang ada di kota Bengkulu yaitu Pantai Panjang, Rumah Pengangsingan Bung Karno, Rumah Fatmawati, Benteng Marlborough, Pantai Tapak Paderi, Danau Dendam Tak Sudah, dan Museum Negeri Bengkulu.

Dalam permasalahan di atas perlu ditinjau kembali kemampuan dari para pegawai dalam menyelesaikan tugas tepat waktu serta memiliki kreatif dan inovatif. Hal ini bisa diasumsikan dengan berbagai faktor salah satunya kemampuan dari para pegawai. Dilihat dari data tingkat pendidikan para pegawai, sebagai berikut:Tabel 1.2 Tingkat Pendidikan

\section{Tabel1}

\section{Tingkat Pendidikan Para Pegawai AyaProvinsi Bengkulu}




\begin{tabular}{|c|c|c|c|c|c|}
\hline \multicolumn{6}{|c|}{ Tingkat Pendidikan } \\
\hline $\begin{array}{l}\text { Ju } \\
\text { m }\end{array}$ & $\begin{array}{l}\text { Pascasa } \\
\text { rjana } \\
\left(\mathrm{S}_{2}\right)\end{array}$ & $\begin{array}{l}\text { Sarj } \\
\text { ana } \\
\left(\mathrm{S}_{1}\right)\end{array}$ & $\begin{array}{l}\text { Dipl } \\
\text { oma }\end{array}$ & $\begin{array}{l}\text { SM } \\
\mathrm{A}\end{array}$ & $\begin{array}{l}\text { SM } \\
P\end{array}$ \\
\hline $\begin{array}{l}\text { la } \\
\text { h }\end{array}$ & $\begin{array}{l}15 \\
\text { Orang }\end{array}$ & $\begin{array}{l}61 \\
\text { Ora } \\
\text { ng }\end{array}$ & $\begin{array}{l}11 \\
\text { Ora } \\
\text { ng }\end{array}$ & $\begin{array}{l}81 \\
\text { Ora } \\
\text { ng }\end{array}$ & $\begin{array}{l}3 \\
\text { Or } \\
\text { an } \\
\text { g }\end{array}$ \\
\hline
\end{tabular}

Sumber: Dinas Kebudayaan dan Pariwisata Provinsi Bengkulu Agustus 2016

Bila diliat dari Tabel 1 staf pegawai yang dominan adalah tamatan SMA. Dengan melihat fakta di lapangan belum mampunya para pegawai untuk mempromosikan wisata Bengkulu melalui media elektonik seperti web Dinas Kebudayaan dan Pariwisata Provinsi Bengkulu untuk lebih diberdayakan lagi. Dengan kemajuan internet yang kian cepat sangat dibutukan pegawai memiliki kemampuan untuk peka terhadap kemajuan elektronik. Serta diliat dari penurunan pengunjung mancanegara ini membuat para pegawai untuk bisa berbahasa asing secara fasih akan tetapi banyak pegawai yang belum terlatih untuk memahami pentingnya menguasai bahasa asing.

Terlepas dari kemampuan para pegawai ini membuat para pegawai tidak mendalami tugas yang diberikan oleh atasan karena mereka hanya sekedar mengerjakan tugas. Ini berakibat buruk terhadap persepsi peran mereka terhadap tugas yang diemban. Dilihat dari data kehadiran dan tingkat pendidikan pegawai kurangnya rasa tanggung jawab terhadap tugas serta lebih memilih untuk menghindari pekerjaan mengakibatkan hasil kerja mereka kurang maksimal. Dalam wawancara dengan atasan di Dinas Kebudayaan dan Pariwisata Provinsi Bengkulu mengenai persepsi peran para pegawai perlu di kembangkan kembali dikarenakan kurangnya keterampilan dan susah memahami tugas yang diberikan oleh atasan dilihat dari kecenderungan tingkat pendidikan yang minim juga menjadi perhatian khusus bagi para atasan untuk menjeleskan pekerjaan dengan berulang sehingga kadang hasil yang diharapkan tidak sesuai dengan permintaan atasan. Sedangkan dalam data tingkat kehadiran yang mana para pegawai lebih sering datang terlambat ini mengakibatkan hasil kerja kurang maksimal dikarenakan kurangnya alokasi waktu sehingga muncul sifat tidak bertanggung jawab. 
Dari penjelasan sebelumnya permasalahan yang ada pada Dinas Kebudayaan dan Pariwisata Provinsi Bengkulu mengakibatkan kepuasan kerja pegawai yang dapat dihubungkan dari hasil kerja mereka. Pendapat sebelumnya yang menghubungkan tingkat absensi (kehadiran) terhadap kepuasan kerja pegawai. Dilihat, dari data tingkat kehadiran maka sikap keterlambatan pegawai untuk datang kekantor serta kurang adanya inisiatif dalam menyelesaikan tugas membuat tingkat kepuasan pegawai belum optimal dalam mencapai kepuasan kerja yang diharapkan. Hal ini juga dijelaskan dalam wawancara dengan atasan di Dinas Kebudayaan dan Pariwisata Provinsi Bengkulu yang mengeluhkan dengan sikap dan perilaku para pegawai dalam menyelesaikan pekerjaan harus diiming-imingkan uang atau upah serta tidak saling membantu apabila ada kegiatan di organisasi dan lebih memilih menyelesaikan pekerjaan yang ditugaskan saja.

\section{KAJIAN PUSTAKA}

\section{Motivasi}

Motivasi mempersoalkan bagaimana caranya mendorong gairah kerja pegawai, agar mereka mau bekerja keras dengan memberikan semua kemampuan dan keterampilannya untuk mewujudkan tujuan organisasi. Hal ini disebabkan dengan motivasi diharapkan setiap pegawai mau bekerja keras dan antusias untuk mencapai produktivitas kerja yang tinggi. Motivasi merupakan hasrat didalam diri seseorang yang menyebabkan orang tersebut melakukan tindakan. Mathis (2006)

\section{Kemampuan}

Kemampuan atau ability merupakan kapasitas/ kemampuan seseorang untuk mengerjakan berbagai tugas dalam pekerjaan tertentu. Setiap orang mempunyai kelebihan dan kekurangan dalam hal kemampuan yang mempunyai relatif unggul atau rendah dibandingkan orang-orang lain dalam melakukan tugas atau kegiatan tertentu. Kemampuan keseluruhan seseorang pada hakekatnya tersusun dari dua faktor, yaitu: kemampuan intelektual dan kemampuan fisik (Robbins, 2008:51-52). Gibson,et.all (2009:96) Ability is a biological or learned trait that permits a person to do something mental or physical. kemampuan merupakan suatu karakter yang dimilikiseseorang atau yang diperoleh melalui belajar, yang menyebabkan seseorang dapat melakukan sesuatu secara mental atau fisik. Kemampuan berkenaan dengan kapasitas setiap orang untuk melakuakan beberapa tugas dalam suatu pekerjaan. Kemampuan juga adalah penilaian terhadap pekerjaan yang dilakukan

\section{Faktor-Faktor Kemampuan}

Kemampuan intelektual adalah kemampuan yang diperlukan untuk mengerjakan kegiatan mental. Secara psikologis individu yang normal memiliki integritas yang tinggi antara fungsi psikis dan fisik. Dengan integritas yang tinggi membuat individu tersebut memiliki konsentrasi diri 
yang baik. Konsentrasi yang baik ini merupakan modal utama individu untuk mampu mengelola dan memberdayagunakan potensi dirinya secara maksimal dalam melaksanakan kegiatan atau aktivitas kerja sehari-hari dalam mencapai tujuan organisasi. Konsentrasi individu dalam bekerja sangat dipengaruhi oleh kemampuan potensi, yaitu kecerdasan pikiran/ Intelligence Quotient (IQ) dsn kecerdasan emosi/ Emotional Quotient (EQ), (Mangkunegara, 2006:53)

\section{Persepsi Peran}

Persepsi peran merupakan gabungan dari beberapa definisi persepsi dan definisi peran. Persepsi merupakan salah satu aspek psikologis yang penting bagi manusia dalam merespon kehadiran berbagai aspek dan gejala di sekitarnya. Persepsi mengandung pengertian yang sangat luas, menyangkut intern dan ekstern. Sugihartono, dkk (2007: 8) mengemukakan bahwa persepsi adalah kemampuan otak dalam menerjemahkan stimulus atau proses untuk menerjemahkan stimulus yang masuk ke dalam alat indera manusia. Bimo Walgito (2004: 70) mengungkapkan bahwa persepsi merupakan suatu proses pengorganisasian, penginterpretasian terhadap stimulus yang diterima oleh organisme atau individu sehingga menjadi sesuatu yang berarti, dan merupakan aktivitas yang integrated dalam diri individu.

Maka penulis dapat menyimpulkan bahwa persepsi peran adalah suatu kemampuan otak dan serangkaian perilaku untuk dapat menginterpretasi, menafsirkan informasi dan melakukan pengamatan terhadap objek dengan harapan dapat memberikan pandangan serta dapat menyikapi situasi tertentu dengan melakukan hak dan kewajiban sesuai dengan kedudukannya. Persepsi peran pada Dinas Kebudayaan dan Pariwisata Provinsi Bengkulu adalah suatu kemampuan otak dan serangkaian prilaku dari pegawai untuk dapat menginterpretasikan, menafsirkan informasi, dan melakukan pengamatan terhadap objek dengan harapan dapat memberikan pandangan serta dapat menikapi situasi yang terjadi dalam organisasi dengan melakukan hak dan kewajiban sesuai dengan kedudukannya.

\section{Kepuasan Kerja}

Menurut para ahli, keberhasilan dalam mengelola sumber daya manusia diindikasikan dengan adanya kepuasan kerja dari para pegawainya, meningkatnya kinerja dan tercapainya tujuan perusahaan. Job satisfaction is a state resulting of employees' perception of how well their job provides those thing are viewed as important (Luthans, 2006:142). Job satisfaction as a positive feeling about one's job resulting from an evaluation of its characteristics. (Robbins 2008: 65).Job satisfaction is a pleasurable feeling that results from the perception that one's job fulfills or allows of one's important job values (Noe, 2010:477).

\section{Kerangka Pemikiran}

Dimensi yang mengacu pada pegawai Dinas Kebudayaan dan Pariwisata Provinsi Bengkulu yaitu pendapat dari Ogan (2006: 266-267) yaitu, 
1. Altuisme (Alturisme). Perlu adanya peningkatan produktivitas rekan kerja. Salah satunya adalah seorang pegawai yang menolong rekan kerja lain akan mempercepat penyelesaian tugas rekan kerjanya dan pada gilirannya meningkatkan produktivitas rekan kerja tersebut.

2. Kesadaran (Conscientious), Penghematan sumber daya yang dimiliki perusahaan secara keseluruhan. Sebagai contohnya yang mencerminkan sikap conscientious yaitu seorang pegawai memiliki conscientious yang tinggi akan meminimalisir pengawasan atasan sehingga pemimpin dapat melaksanakan tugas yang penting lainnya dan pegawai tersebut dapat menyelesaikan pekerjaan tepat waktu.

3. Sikap Sportif (Sportmanship), Penghematan energi dan sumber daya yang langka untuk memelihara fungsi kelompok. Hal ini terlihat ketika pegawai memperlihatkan perilaku menolong dimana perilaku tersebut dapat meningkatkan semangat, moril dan kerekatan sebuah kelompok. Sehingga para pegawai memiliki sikap positif dalam menyelesaikan tugas dan para pegawai tidak memiliki sifat banyak mengeluh dan melihat kesalahan sebagai sisi negatif.

4. Kesopanan (Courtesy), Sebagai sarana efektif untuk mengkoordinasikan kegitankegiatan kelompok kerja. Salah satu contoh perilaku courtesy seperti memberikan informasi tentang pekerjaan kepada anggota dari tim lain akan menghindari munculnya masalah yang membutuhkan waktu dan tenaga untuk diselesaikan.

5. Partisipasi Aktif (Civic Virtue). Meningkatkan stabilitas kinerja di setiap bagian. Ketika pegawai membantu tugas pegawai lain yang tidak hadir di tempat kerja atau yang mempunyai beban kerja berat maka akan meningkatkan stabilitas dari kinerja tiap bagian.

Secara tidak langsung motivasi dan kemampuan memiliki pengaruh terhadap perilaku individu dan kinerja, akan tetapi pegawai juga membutuhkan persepsi peran akurat untuk melakukan pekerjaan mereka dengan baik (McShane dan Von Glinow, 2015:34). Hal ini juga dapat dijelaskan bahwa peningkatan motivasi dan kemampuan perlu ditunjang dengan persepsi peran dari para pegawai dalam penyelesaian tugas. Sehingga dengan diberikan pemahaman dalam penyelesaian tugas akan menghasilkan tugas yang diharapkan oleh atasan sehingga dapat mencapai tujuan organisasi.

\section{Hipotesis}

Berdasarkan kerangka pemikiran yang diuraikan dan pradigma penelitian yang digambarkan diatas, maka penyusunan mengemukakan suatu hipotesis untuk rumusan masalah dan tujuan penelitian sebagai berikut:

- $\mathrm{H}_{1}$ : Motivasi berpengaruh secara siginifikan terhadap kepuasan kerja pegawai di Dinas Kebudayaan dan Pariwisata Provinsi Bengkulu.

- $\mathrm{H}_{2}$ : Kemampuan berpengaruh secara siginifikan terhadap kepuasan kerja pegawai di Dinas Kebudayaan dan Pariwisata Provinsi Bengkulu.

- $\mathrm{H}_{3}$ : Persepsi peran berpengaruh secara siginifikan terhadap kepuasan kerja pegawai di D 


\section{METODE PENELITIAN}

Jenis penelitian ini termasuk penelitian deskriptif verifikatif dengan jenis metode survei. Metode survey digunakan dengan tujuan, penelitian dapat bersifat deskriptif dan juga verifikatif, ekplanatori dan konfirmatori, data dikumpul dari sampel yang telah ditentukan, data variabel penelitian dijaring dengan menggunakan alat pengumpulan data yaitu kuesioner. Sedangkan dengan penelitian verifikatif dimaksud untuk menguji kebenaran melalui pengumpulan data di lapangan. Penelitian ini terdiri dari 4 variabel yang diteliti dan dibagi menjadi 3 jenis variabel yaitu variabel bebas (independent variabel)motivasi $\left(\mathrm{X}_{1}\right)$, kemampuan $\left(\mathrm{X}_{2}\right)$, persepsi peran $\left(\mathrm{X}_{3}\right)$ dan variabel terikat (dependent variabel)kepuasan kerja pegawai.(Y).Untuk memperoleh data yang relevan, dapat dipercaya dan valid, maka dalam penelitian ini terdiri dari dua jenis data berdasarkan sumbernya, data yang digunakan yaitu data primer dan data sekunder. Berdasarkan sumber data yang digunakan teknik pengumpulan data yang digunakan adalah penelitian lapangan (field research) melalui interview dan kuesioner lalu penelitian kepustakaan (library research). Teknik penentuan sampel yang digunakan adalah proportionate stratified random sampling yang merupakan kelompok dari probability sampling. Teknik penarikan sampel proportionate stratified random sampling digunakan karena populasinya tidak homogeny atau berstrata, dalam penelitian ini berdasarkan bagian, sesuai dengan yang diungkapkan Sugiyono (2007:75). Data hasil penelitian (kuesioner) terlebih dahulu dilakukan uji validitas dan uji reliabilitas untuk menguji ketepatan alat ukur yang digunakan dalam penelitian berupa pernyataan dalam kuesioner.

\section{HASIL PENELITIAN DAN PEMBAHASAN}

Dari hasil olah data terlihat bahwa pegawai merasa pekerjaan yang di jalankan sekarang telah sesuai dengan apa yang diinginkannya dengan melihat responden berdasarkan usia 41-50 tahun masih menjalankan tugas yang diberikan serta peran dari atasan sudah sesuai dengan peran mereka sebagai acuan dan memberikan arahan dalam penyelesaian tugas bagi pegawainya. Akan tetapi pegawai masih merasa keterampilan yang dimiliki dapat membantu mereka dalam bekerja yang terlihat dalam 35\% menyatakan tidak setuju. 
Tabel 4.5.1

Hasil Koefisien Jalur X terhadap Y

Coefficients $^{a}$

\begin{tabular}{|c|c|c|c|c|c|c|}
\hline & & Unstandardized & Coefficients & $\begin{array}{c}\text { Standardized } \\
\text { Coefficients }\end{array}$ & & \\
\hline & & B & Std. Error & Beta & $\mathrm{t}$ & Sig. \\
\hline 1 & (Constant) & 5.210 & 1.006 & & 5.176 & .000 \\
\hline & KEMAMPUAN X1 & .791 & .096 & .573 & 8.238 & .000 \\
\hline & PERSEPSI PERAN X2 & 1.066 & .184 & .402 & 5.780 & .000 \\
\hline
\end{tabular}

a. Dependent Variable: KEPUASAN KERJA Y

Dari hasil perhitungan diperoleh koefisien jalur untuk kemampuan $\left(\mathrm{P}_{\mathrm{yx} 1}\right)$ sebesar 0,573 dan koefisien jalur untuk persepsi peran $\left(\mathrm{P}_{\mathrm{yx} 2}\right)$ sebesar 0,402.Berdasarkan koefisien jalur yang diperoleh, dapat ditentukan besar pengaruh secara bersama-sama (koefisien determinasi) Kemampuan dan Persepsi Peran terhadap Kepuasan Kerja dari hasil perkalian koefisien jalur dengan korelasi antara variabel sebab dan variabel akibat.Hasil perhitungan pengaruh secara bersama-sama kemampuan dan persepsi peran terhadap kepuasan kerja dapat dilihat pada tabel dibawah ini:

Tabel 4.5.2

Hasil Koefisien Determinasi (pengaruh total) X terhadap Y

\begin{tabular}{l}
\begin{tabular}{|l|r|r|r|r|}
\hline Model & $\mathrm{R}$ & $\mathrm{R}$ Square & $\begin{array}{c}\text { Adjusted R } \\
\text { Square }\end{array}$ & $\begin{array}{c}\text { Std. Error of the } \\
\text { Estimate }\end{array}$ \\
\hline 1 & $.955^{\mathrm{a}}$ & .912 & .911 & 2.541 \\
\hline
\end{tabular} \\
\hline
\end{tabular}

Tabel 4.5.3 Hasil Uji F

ANOVA $^{\mathrm{b}}$

\begin{tabular}{|ll|r|r|r|r|r|}
\hline Model & & Sum of Squares & Df & Mean Square & F & Sig. \\
\hline 1 & Regression & 7383.558 & 2 & 3691.779 & 571.595 & $.000^{\mathrm{a}}$ \\
& Residual & 710.460 & 110 & 6.459 & & \\
& Total & 8094.018 & 112 & & & \\
\end{tabular}

a. Predictors: (Constant), PERSEPSI PERAN X2, KEMAMPUAN X1

b. Dependent Variable: KEPUASAN KERJA Y 
Tabel 4.5.4

Uji Hipotesis Pengaruh secara Parsial

\begin{tabular}{|l|l|c|c|c|c|}
\hline No & \multicolumn{1}{|c|}{ Hipotesis } & $\begin{array}{c}\text { Koefisien } \\
\text { Jalur }\end{array}$ & $\mathbf{t}_{\text {hitung }}$ & $\mathbf{t}_{\text {tabel }}$ & Kesimpulan Statistik \\
\hline 1 & $\begin{array}{l}\text { Kemampuan berpengaruh } \\
\text { terhadap kepuasan kerja }\end{array}$ & 0,573 & 8,238 & 1,982 & Signifikan $\left(\mathrm{H}_{0}\right.$ ditolak) \\
\hline 2 & $\begin{array}{l}\text { Persepsi peran berpengaruh } \\
\text { terhadap kepuasan kerja }\end{array}$ & 0,402 & 5,780 & 1,982 & Signifikan $\left(\mathrm{H}_{0}\right.$ ditolak) \\
\hline
\end{tabular}

Sumber : Data primer yang telah diolah

Tabel 5.5.5

Besarnya Pengaruh Langsung dan Tidak Langsung $\mathrm{X}_{1}$ dan $\mathrm{X}_{2}$ terhadap $\mathrm{Y}$

\begin{tabular}{|c|c|c|c|c|c|}
\hline \multirow{2}{*}{ Variabel } & \multirow{2}{*}{$\mathrm{P}_{\mathrm{yxi}}$} & $\begin{array}{c}\text { Pengaruh Langsung } \\
(\text { dalam\%) }\end{array}$ & \multicolumn{2}{|c|}{$\begin{array}{c}\text { Pengaruh Tidak Langsung } \\
\text { (dalam\%) }\end{array}$} & \multirow{2}{*}{$\begin{array}{c}\text { Total } \\
\text { Pengaruh }\end{array}$} \\
\cline { 4 - 5 } & & $\mathrm{X}_{1}$ & $\mathrm{X}_{2}$ & $54 \%$ \\
\hline $\mathrm{X}_{1}$ & 0,573 & $32,9 \%$ & - & $21,1 \%$ & $37,2 \%$ \\
\hline $\mathrm{X}_{2}$ & 0,402 & $16,1 \%$ & $21,1 \%$ & - & $91,2 \%$ \\
\hline \multicolumn{4}{|r}{} \\
\hline
\end{tabular}

Secara parsial pengaruh kemampuan terhadap kepuasan kerja sebesar 54\% dan pengaruh persepsi peran terhadap kepuasan kerja sebesar 37,2\%. Hasil perhitungan yang diperoleh memperlihatkan adanya pengaruh kemampuan dan persepsi peran terhadap kepuasan kerja sebesar 91,2\%. Sedangkan $8,8 \%$ sisanya dipengaruh variabel-variabel lain diluar kedua variabel yang diamati.

Berdasarkan hasil analisis yang dilakukan memperlihatkan bahwa ada pengaruh yang signifikan dan positif antara keterlibatan kerja terhadap kinerja pegawai dengan dimediasi komitmen organisasi. Sehingga semakin baik atau tinggi variabel keterlibatan kerja maka akan semakin meningkat juga variabel kinerja pegawai dan semakin baik variabel komitmen organisasi maka mediasi yang dapat memperkuat akan terbentuk.

Keterlibatan kerja merupakan salah satu variabel yang berpengaruh sigfikan terhadap komitmen organisasi. Dalam penelitian ini dapat ditunjukkan dengan nilai $\beta$ sebesar 0,853 , t-hitung sebesar 19.310 dengan signifikansi $0,000(\rho<0,005)$ yang memberi pemahaman bahwa setiap penambahan satu satuan atau satu tingkatan keterlibatan kerja akan berdampak pada meningkatnya komitmen organisasi sebesar 0.853. Dalam hal ini keterlibatan kerja yang tinggi menyebabkan individu lebih berkomitmen terhadap organisasinya, sebaliknya keterlibatan kerja yang rendah akan menjadikan individu kurang berkomitmen terhadap organisasinya. Hal ini dikarenakan keterlibatan kerja merupakan variabel yang penting dalam 
kehidupan banyak orang (Blau dan Bloal, 1987). Keterlibatan kerja yang tinggi berperan dalam membentuk performance kerja, kualitas, dan kuantitas hasil kerja yang lebih besar serta efisiensi kerja yang tinggi (Uygur dan Killic, 2009).

Bedasarkan hasil penelitian yang sudah dilakukan bahwa terlihat adanya pengaruh yang positif dan signifikan dari variabel keterlibatan kerja terhadap kinerja pegawai pada beberapa Kantor dinas di Kota Bengkulu. Hal ini memberikan kesimpulan bahwa keterlibatan kerja yang tinggi maka kinerja pegawainya juga akan lebih baik untuk menunjang pekerjaan mereka sebagai seorang pegawai, seperti halnya kemampuan mereka dalam berpikir untuk memahami keadaan, dan menjalankan tugas mereka dengan penuh tanggung jawab sesuai dengan standar oprasi dan tenggat waktu yang ada. Serta mereka bisa menerapkan pengetahun dan keahlian mereka sesuai dengan kebutuhan sebagai seorang pegawai.

Penelitian ini juga menunjukan bahwa komitmen organisasi berpengaruh terhadap kinerja pegawai dengan pengaruh sebesar 72,4 \%, seperti halnya yang dikemukakan oleh Streers (1991) bahwa karyawan yang berkomitmen rendah akan berdampak pada turnover tingginya absensi, meningkatnya kelambatan kerja dan kurangnya intensitas untuk bertahan sebagai karyawan di organisasi tersebut, rendahnya kualitas kerja dan kurangnya loyalitas pada perusahaan. Ada pengaruh komitmen afektif hasil organisasi seperti kinerja dan perputaran karyawan bila dibandingkan dengan dua dimensi komitmen lain (Robbins, 2008). Penelitian yang dilakukan oleh Suswati dan Budianto mengatakan adapun secara parsial komitmen afektif mempunyai pengaruh positif dan signifikan terhadap kinerja. Kemudian menurut hasil riset Frederick Reichheld (1993), dalam the loyalty Effect, menunjukkan bahwa ada korelasi positif antara komitmen karyawan dengan tingkat kinerja perusahaan. Dari ketiga jenis komitmen, komitmen afektif adalah yang paling diinginkan oleh perusahaan. Karyawan yang memiliki komitmen afektif akan cenderung tetap tinggal (bekerja dalam perusahaan), mereka akan merekomendasikan kepada orang lain bahwa perubahan tempat bekerjanya merupakan tempat yang bagus untuk bekerja, mereka akan suka melakukan kerja tambahan untuk perusahaan, mereka akan mau memberikan saran-saran bagi perbaikan dan kemajuan perusahaan (Fuad Mas'ud ,2002).

\section{KESIMPULAN}

\section{Kesimpulan}

Berdasarkan dari hasil penelitian dan pembahasan pada bab sebelumnya mengenai pengaruh kemampuan dan persepsi peran terhadap kepuasan kerja pegawai di Dinas Kebudayaan dan Pariwisata Provinsi Bengkulu, maka dapat ditarik kesimpulan sebagai berikut: 
1. Gambaran kemampuan, persepsi peran, kepuasan kerja di Dinas Kebudayaan dan Pariwisata Provinsi Bengkulu sebagai berikut:

a. Kemampuan di Dinas Kebudayaan dan Pariwisata Provinsi Bengkulu dalam hasil penelitian, memiliki pernyataan pegawai dapat memilih saran/ pendapat yang terbaik sehingga mempermudah penyelesaian pekerjaan terlihat lebih banyak menyatakan tidak setuju. Hal ini menjelaskan karyawan belum dapat memilih saran/ pendapat yang terbaik untuk mempermudah penyelesaian pekerjaan sehingga pihak pegawai perlu meningkatan pengembangan diri mereka untuk dapat memberikan keputusan dalam penyelesaian pekerjaan..

b. Persepsi peran di Dinas Kebudayaan dan Pariwisata Provinsi Bengkulu memiliki nilai terendah terletak pada indikator pegawai sangat memahami dengan baik perintah atasan yang diberikan kepada pegawai. Hal ini dikarenakan para pegawai masih belum memahami perintah yang diberikan oleh atasan. Sehingga masih dibutuhkan peran dari atasan untuk dapat menjelaskan dan membimbing para pegawai untuk dapat menyelesaikan tugas yang diberikan.

c. Kepuasan kerja di Dinas Kebudayaan dan Pariwisata Provinsi Bengkulu merasa keterampilan yang dimiliki belum mampu membantu mereka dalam bekerja sehingga pegawai membutuhkan pelatihan dan pengembangan diri sehingga memiliki keterampilan lebih salah satunya keterampilan dalam bahasa asing khususnya bahasa inggris.

2. Dalam hasil pengaruh kemampuan terhadap kepuasan kerja pegawai terdapat kontribusi yang diberikan oleh kemampuan cukup besar, dan pengaruh persepi peran terhadap kepuasan kerja memiliki persepsi peran yang cukup mempengaruhi kepuasan kerja. Adanya pengaruh kemampuan dan persepsi peran terhadap kepuasan kerja, ini berarti kemampuan dan persepsi peran yang dijalankan/dianut pada Dinas Kebudayaan dan Pariwisata bisa diterima atau mendukung terciptanya kepuasan kerja pegawai.

\section{Saran}

Berdasarkan hasil penelitian, saran yang dapat diajukan bagi Dinas Kebudayaan dan Pariwisata Provinsi Bengkulu adalah sebagai berikut: a) Perlu diberikan arahan untuk menyusun rencana kedepan dalam pengembangan pariwisata. Sehingga pegawai dapat membuat kegiatan baik itu bazaar ataupun ke sekolah-sekolah untuk mempromosikan pariwisata dan juga mengajak kepada masyarakat untuk lebih menjaga dan mengajak untuk partisipasi dalam memajukan wisata yang ada di Bengkulu. b) Peran atasan untuk dapat memberikan pemahaman lebih dalam menjelaskan dan membimbing para pegawai sehingga dapat menyelesaikan tugas yang diberikan. c) Sedangkan untuk meningkatkan kepuasan kerja pegawai, khususnya memberikan pekerjaan sesuai dengan minat dan potensi yang ada pada para pegawai sehingga hasil kerja bisa optimal. d) maka dari itu para pegawai nantinya dapat berperan aktif dalam memberikan perbaikan baik di tim kerja, divisi maupun di Dinas dan berinisiatif untuk dapat 
mengembangkan kebudayaan dan pariwisata di Dinas Kebudayaan dan Pariwisata Provinsi Bengkulu.

\section{DAFTAR PUSTAKA}

Agustiar, Shofia Amin dan Edward. 2005. Pengaruh Praktek Kepemimpinan, Pengembangan Pegawai Dan Persepsi Peran Terhadap Kinerja Penyidik Ppns Hak Kekayaan Intelektual Kantor Wilayah Departemen Hukum Dan Hak Asasi Manusia Se-Sumatera.Jurnal Siasat Bisnis No.10 Vol.2

Ahdiyana, M. (2009) Dimensi OCB Dalam Kinerja Organisasi. Artikel Belajar. Yogyakarta: Universitas Negeri Yogyakarta

Anoraga, Pandji. 2004. Manajemen Bisnis. Jakarta: PT. Rineka Cipta.

Colquitt Jason A, LePine Jeffery A and Wesson Michael J. 2009.Organizational Behavior Improving Performance and Commitment in The Workplace, International Edition. New York : McGraw-Hill

Davis, Keith, 2002. Fundamental Organization Behavior, diterjemahkan Agus Dharma, Jakarta ; Erlangga

Davis Keith and Newstrom John W., 2002. Organizational Behavior, International Edition. New York: McGraw-Hill.

Gibson,et.all, 2009.Organization( Behavior structure procces ). Singapore: Mc. Graw Hill.

Gomes, Faustino Cardoso. 2003.Manajemen Sumber Daya Manusia, Yogyakarta: Penerbit Andi,.

Greenberg, Jerald. 2011. Behavior in Organizations. England : Pearson Education Limited.

Haidjrachman, Husnan. S. 2002. Managemen Personalia. Yogyakarta : Bpfe.

Hasibuan, Melayu SP., 2000.Manajemen Sumber Daya Manusia, Jakarta: Gunung Agung,.

Ishak,Arep. 2003. Manajemen Sumber Daya Manusia. Jakarta : PT. Gramedia Widia Sarana.

Ivancevich, J.M. 2001. Human Resources Management. 8th $^{\text {th }}$ Edition. McGraw-Hill

Kreitner Robert \& Kinicki Angelo. 2007.Organizational Behavior, Seventh Edition. New York: McGraw-Hill.

Krishnakumar, Sukumarakurup dan Hopkins, Kay. 2014. The role of emotion perception ability in motivation to lead. Management Research Review. Hal: 334-347.

Luthan, Fred.(2006). Perilaku Organisasi (terjemahan Vivin Andika et.al) Yogyakarta: Penerbit Andi

Mangkunegara, Anwar Prabu.2006. Evaluasi Kinerja Sumber Daya Manusia.Bandung: PT Refika Aditama.

Marinda, Vina Silviani. 2012. Pengaruh Kepemimpinan Transformasional dan Employee Engagement terhadap Organizational Citizenship Behavior (OCB) serta dampaknya terhadap Keefektifan Divisi Di PT. Industri 
Telekomunikasi Indonesia (PERSERO). Tesis. Fakultas Ekonomi dan Bisnis Universitas Padjadjaran.

Martoyo.2000. Manajemen Sumber Daya Manusia Edisi 4. Yogyakarta: BPFEUGM

Mathis, Robert L dan Jackson, John H. 2006. Human Resource Management. Alih Bahasa. Jakarta: Salemba Empat.

McShane, Steven L dan Von Glinow, Marry Ann. 2015.Organizational Behavior. Singapore: Mc. Graw Hill Education

Moh. Nazir, 2003, Metode Penelitian, Cetakan Kelima, Jakarta, Ghalia. Indonesia.

Noe, dkk. 2010. Human Resource Management. New York : McGraw-Hill

Organ, D, W. 2006. Organizational Citizenship Behavior. Illustration Edition, Sage Publication, Inc.

P, Ricardo. 2012. Pengaruh Komitmen Organisasional dan Iklim Organisasi Terhadap Organizational Citizenship Behavior (OCB) Pada Tenaga Perawat Di RS. PELNI Jakarta. Tesis. Fakultas Ekonomi dan Bisnis Universitas Padjadjaran.

Podsakoff, et all (2000). Organizational Citizenship Behavior: Acritical Reviewof The Theoritical And Empirical Literature And Suggsestion For Future Research. Journal Of Management. 26/3. p.513-563.

Priadana, Sidik dan Ruswandi, Iwan. 2013. Pengaruh Kemampuan Kerja dan Motivasi Terhadap Kepuasan Kerja Serta Implikasinya Pada Kinerja Pegawai Dinas Pertambangan dan Energi Provinsi Jawa Barat.Jurnal Ekonomi, Bisnis, \& Entrepreneurship No.2 Vol.7

Raho. Bernard.2007.Teori Sosiologi Modern. Jakarta: Prestasi Pustakaraya

Rivai, Veithzal. 2008. MSDM untuk Perusahaan (Dari Teori ke Praktik). Edisi satu. Jakarta: PT Raja Grafindo Persada

Robbins, Stephen. P. 2008. Perilaku Organisasi. Edisi Kesepuluh. Edisi Lengkap. Alih Bahasa Drs. Benyamin Molan. Jakarta: PT Macanan Jaya Cemerlang

Sekaran, U. 2006. Metode Penelitian Untuk Bisnis 1. (4th Ed). Jakarta: Salemba Empat.

Senen, Syamsul Hadi dan Solihat, Siti. 2008. Pengaruh Motivasi Kerja Dan Kemampuan Kerja Karyawan Terhadap Produktivitas Kerja Karyawan Pada Pt. Safilindo Permata. Jurnal Strategic Pendidikan Manajemen Bisnis.Vol.7 Hal: 14.

Siagian, Sondong. P. 2002. Kiat Meningkatkan Produktivitas Kerja. Jakarta: PT Rineka Cipta.

Siahaan, Betty Zelda. 2009. Pengaruh Kemampuan Kerja, Persepsi Peran Dan Motivasi Kerja Terhadap Kinerja Pegawai Administrasi Universitas Negeri Jakarta. Jurnal Manajemen Pendidikan. Hal: 248-258.

Singarimbun, M dan Effendi,S. 2003. Metodologi Penelitian Survey. Jakarta: Erlangga.

Soekanto, Soerjono. 2009:212-213, Peranan Sosiologi Suatu Pengantar, Edisi Baru, Jakarta:.Rajawali Pers,

Soelaiman, 2007, Manajemen Kinerja ; Langkah Efektif untuk Membangun, Mengendalikan dan Evaluasi Kerja, Cetakan Kedua, Jakarta: PT. Intermedia Personalia Utama. 
Sugihartono, dkk. 2007. Psikologi Pendidikan.Yogyakarta: UNY Press Sugiyono. 2007. Metode Penelitian Pendidikan. Bandung: Alfabeta.

Suharman, 2005. Psikologi Kognitif, Surabaya: Srikandi.

Supardi dan Syaiful Anwar. 2002. Dasar - dasar Perilaku Organisasi. Yogyakarta: UII Press.

Supranto, J. 2002. Statistik Teori dan Aplikasi, Jakarta: Erlangga.

Walgito, Bimo, 2004. Pengantar Psikologi Umum, Yogyakarta:.Andi

Winarny, Wieny. 2011. Pengaruh Perilaku Pemimpin dan Motivasi Kerja Terhadap Kepuasan Kerja Karyawan di Lingkungan PT.Pupuk Kujang Cikampek. Tesis. Fakultas Ekonomi dan Bisnis Universitas Padjadjaran. 